Colloquia Litteraria UKSW

112011

WOJCIECH KUDYBA

\title{
DRZWI DO POKOJU
}

\begin{abstract}
Bohater wciąż przebywa w stanie zagrożenia własnego ,ja" - przez upływ czasu, nacisk podświadomości, ciężar dziedzictwa, środowisko, kaprysy pamięci. Albo poszukuje tożsamości w głębinach swojej osobowości, albo projektuje niepokój samopoznawczy na otoczenie ${ }^{1}$.
\end{abstract}

Cytat pochodzi z monografii twórczości Czesława Miłosza i sygnalizuje istotny dla poety krąg problemów związanych z pytaniami o tożsamość. Badacz nie tylko odnotowuje ich zastanawiającą natarczywość, ale odsłania też ich semantykę. Przekonująco sytuuje je w kontekście doświadczenia od-łączenia, obejmującego rozmaite aspekty egzystencji: geograficzny, kulturowy, społeczny, przede wszystkim zaś - duchowy ${ }^{2}$. Im więcej dziś wiemy o rozproszonych w dziele poety obrazach „nietożsamości” i metafizycznego wydziedziczenia ${ }^{3}$, tym bardziej zwraca uwagę późna twórczość poety i pojawiające się w niej ślady przeżyć zgoła przeciwnych. Ciemny awers figur rozdzielenia, poszukiwania siebie uzyskuje w ostatnich tomach poety jasny rewers w postaci tropów pokoju: pojednania z sobą i światem. Aby

\footnotetext{
1 Aleksander Fiut, Moment wieczny. Poezja Czesława Miłosza, Kraków 1998, s. 209.

2 Tamże, s. 244-246. Por także tegoż, Pytanie o tożsamość, Kraków 1995 oraz Marian Stala, ,Szukając tego, co jest Rzeczywiste”, w: tegoż, Chwile pewności. 20 szkiców o poezji i krytyce, Kraków 1991, s. 51-86. Cenne rozszerzenie problematyki Miłoszowego „wygnania” przynosi tekst Przemysława Dakowicza Wygnanie jako sytuacja egzystencjalna w poezji Czesława Miłosza, w: P. Dakowicz, Helikon i okolice. Notatki o poezji wspótczesnej, Sopot 2008, s. 63-79.

3 Interesująco pisze o nich w swej ostatniej książce Łukasz Tischner; por. tegoż, Miłosz w krainie odczarowanej, Gdańsk 2011.
} 
przyjrzeć się im dokładniej, wybrałem jeden wiersz: Późna dojrzałość $\mathrm{z}$ tomu Druga przestrzeń ${ }^{4}$.

Nieprędko, bo dopiero pod dziewięćdziesiątkę, otworzyły się drzwi we mnie i wszedłem w klarowność poranka.

Czułem, jak oddalają się ode mnie, jeden po drugim, niby okręty, moje wcześniejsze żywoty razem z ich udręka.

Ukazywały się, przyznane mojemu rylcowi, kraje, miasta, ogrody, morskie zatoki, dla opisania ich lepiej niż dawniej.

Nie byłem oddzielony od ludzi, żal i litość nas połączyły i mówiłem: zapomnieliśmy, że jesteśmy wszyscy dziećmi Króla.

Bo przychodzimy stamtąd, gdzie jeszcze nie ma podziału na Tak i Nie, ani podziału na jest, będzie i było.

Jesteśmy nieszczęśni, bo robimy użytek z mniej niż setnej części daru, który otrzymaliśmy na naszą długą podróż.

Chwile z wczoraj i sprzed wieków: cios miecza, malowanie rzęs przed lustrem $z$ wygładzonego metalu, śmiertelny strzał $\mathrm{z}$ muszkietu, zderzenie karaweli z rafą mieszkają w nas i czekają na dopełnienie.

Zawsze wiedziałem, że będę robotnikiem w winnicy, tak samo jak wszyscy ludzie żyjący równocześnie ze mną, świadomi tego czy nieświadomi.

Na początku utworu poeta umieścił metaforę drogi. W wielu jego wierszach staje się ona figurą tęsknoty. Opowiada o dążeniu - o niezgodzie i woli poszukiwanias. Czasownik ,wszedłem” ma jednak postać dokonaną. Powiadamia nie o dochodzeniu, lecz o dojściu; nie

4 Czesław Miłosz, Druga przestrzeń, Kraków 2002, s. 8.

5 Tak jest m.in. w tomie Trzy zimy, o czym interesująco pisze Ewa Kołodziejczyk, por. tejże, Podróż syna marnotrawnego. O motywie romantycznym w ,Trzech zimach” Czesława Miłosza, „Pamiętnik Literacki” 2001, z. 3, s. 135-169. 
o wysiłku, lecz o osiągnięciu; nie o pragnieniu, lecz o satysfakcji. Jej kształt obrysowują kolejne symbole. Dzięki nim dowiadujemy się, że ruch odbywa się w przestrzeni mentalnej, we wnętrzu ,ja”; że oznacza dojście do samego siebie, odnalezienie w sobie tej osobowej głębi, z której wynikają akty poznania i woli, dotarcie do samych źródeł własnej tożsamości. Miłoszowe „drzwi we mnie” przypominają „drzwi serca" - znane mistykom chrześcijańskim i niechrześcijańskim ${ }^{6}$. Być może da się w omawianym wierszu wysłyszeć echo swedenborgiańskich fascynacji poety. „Mistrz” pisał o „drzwiach percepcji”, obraz odnowienia władz poznawczych pojawia się też w Późnej dojrzałości. Pejzaż klarownego poranka jest $\mathrm{w}$ liryku raczej projekcją stanu wewnętrznego bohatera, niż „obiektywną” własnością topografii. Wydaje się, że skryte w nim konotacje światła i przejrzystości (które często w idiolekcie poety są znakami transcendencji ${ }^{8}$ ) odsyłają do sfery życia duchowego i rozwoju wewnętrznego (medytacji ${ }^{9}$ ? iluminacji ${ }^{10}$ ?). Nie siląc się na precyzyjną klasyfikację zjawiska (czy jest ona koniecznie potrzebna?) powiedzmy, że bohater - odrywając się od wszystkiego, co zewnętrzne, schodząc w głąb siebie - odkrywa coś, co w nim samym pozostaje nieredukowalne i niezmienne (chciałoby się powiedzieć - duchowe); zostawiając za sobą to, co powierzchowne poznaje swą najgłębszą istotę, swe prawdziwe, pierwotne, a zarazem ostateczne ,ja" - czujące i poznające.

6 Por. Dorothea Forstner, Świat symboliki chrześcijańskiej, przekł. i oprac. Wanda Zakrzewska, Paweł Paciarek, Ruszard Turzyński, wybór il. i koment. Tamara Łozińska, Warszawa 1990, s. 384.

7 Por. Signe Toksvig, Emanuel Swedenborg. Uczony i mistyk, przekł. Ireneusz Kania, Kraków 2002, s. 187.

8 Wspomina o tym m.in. Krzysztof Dybciak w eseju Poezja petni istnienia, w: tegoż, Trudne spotkanie. Literatura polska XX wieku wobec religii, Kraków 2005, s. 115.

9 O medytacyjnym nachyleniu tekstów poety szerzej piszę w szkicu Żywioł medytacyjny w liryce Czesława Miłosza, ,Topos” 2002, nr 4-5 (65-66), s. 7-15.

10 Por. Zofia Zarębianka, Iluminacje Czesława Miłosza zapisane w jego wierszach, w: Poetyka i semantyka doświadczeń religijnych $w$ literaturze, red. Agnieszka Bielak, Piotr Nowaczyński, Lublin 2011, s. 351-360. 


\section{Od-nowa}

Zastanawia sposób, w jaki bohater doświadcza czasu. Określenia „dopiero”, „nieprędko” pozwalają przypuszczać, że przeszłość jest przez niego odczuwana jako czas niepełny, osobliwy długi antrakt, wypełniony „pustym” oczekiwania. Czas pełny zaczyna się w chwili „przebudzenia”, w momencie uchylenia wewnętrznych drzwi. Od tego momentu nabiera on właściwej dynamiki, od tej chwili jest odczuwany jako temporalność wypełniona istotnymi, znaczącymi wydarzeniami. Znawcy fenomenu doświadczenia religijnego powiedzieliby zapewne, że w podobny sposób odczuwają czas wszyscy doświadczający przełomu duchowego ${ }^{11}$. Była o tym mowa: otwarcie drzwi serca, odkrycie własnej duchowości oznacza w wierszu radykalną zmianę sposobu bycia-w-świecie, oddalającą czy nawet unieważniającą wszystko, co zdarzyło się wcześniej. Istotnym komponentem przemiany staje się w liryku - znane psychologom religii badającym fenomen duchowego „przebudzenia” - przeżycie pokoju, ulgi i wyzwolenia ${ }^{12}$. Akwatyczna metaforyka nakreślonego przez poetę obrazu skłania do myślenia o odczuciach oczyszczenia. Bohater nie tylko odkrywa „zewnętrzność" tego, co dotąd uważał za własne, wobec ,ja”, ale dostępuje też przedziwnego daru wyzwolenia od tych warstw „siebie”, które - związane z dawnymi sposobami życia i myślenia - nieoczekiwanie odsłoniły swój ,powierzchniowy” charakter (ważny - lecz nie decydujący o tożsamości ,ja”).

Wypowiedź podmiotu prowokuje do pytań o powody minionej udręki. Obrazy wypełniające utwór pozwalają dostrzec kontury odpowiedzi. Nie brzmi ona dla czytelników Miłoszowej poezji obco: źródłem cierpień okazuje się osobliwe zamknięcie na świat i jego wezwanie, na ludzi i ich los, na dar, w jaki nas wyposażono. Pisarz wielokrotnie wspomina w swych tekstach o skłonności ego do „monadyczności”, do umieszczania „siebie” ponad roszczeniami świata i wołaniem

11 Przekonuje o tym wznowiona niedawno u nas praca Williama Jamesa: Odmiany doświadczenia religijnego. Studium natury ludzkiej (Warszawa 2011), niegdyś przełomowa, dziś kluczowa dla badań nad fenomenem przeżyć religijnych.

12 Por. np. Antoni J. Nowak, Homo religiosus et homo novus, w: Homo novus, red. A.J. Nowak, Teresa Paszkowska, Lublin 2002, s. 11-29. 
ludzi, poza dobrem i złem ${ }^{13}$. Filozofowie z bliskiego Miłoszowi kręgu personalizmu wyraźnie podkreślają dynamiczny sposób istnienia człowieka. „Ja” może funkcjonować wyłącznie na poziomie samotnego „indywiduum”, ale może też dojrzewać, może stawać się osobą, tj. podejmować zobowiązania wobec świata i innych osób ${ }^{14}$. Wydaje się, że autor liryku używa pojęcia dojrzałości w takim właśnie znaczeniu. Opisane w Późnej dojrzałości doświadczenie rozpoznania bliskie jest temu, co personaliści nazywali rozpoznaniem siebie jako osoby, odkryciem osobowego wymiaru własnego istnienia ${ }^{15}$. Zapoznany przez ludzi dar, o którym mówi bohater, jest być może właśnie „wyposażeniem" człowieka jako osoby: świadomością skierowaną ku prawdzie i wolnością ukierunkowaną w stronę innych. Wchodząc w siebie, bohater odkrywa relacyjny charakter własnej toż-samości, odkrywa siebie-w-świecie, siebie-wśród-innych, siebie-wobec-wartości. Głębokie doświadczenie ,ja” prowadzi w liryku ostatecznie poza ego - w stronę roszczeń ludzkiego świata. „Aby zachować wewnętrzność, trzeba wyjść poza nią" - przekonywał Emmanuel Mounier ${ }^{16}$.

To, co zaskakuje w wypowiedzi poety nie jest więc związane z diagnozą realnych źródeł zła, lecz z doświadczeniem nie mniej realnego uwolnienia od jego skutków. W spokojnych, ,psalmicznych” frazach utworu kryje się poczucie pewności podmiotu, że to, czego doświadcza, nie jest złudzeniem, lecz rzeczywistością, jakby mówił sobie i nam: „to, co czuje, jest prawdziwe”. Naturalnym komponentem takiego stanu wydaje się radość. Zdarza się (piszą o tym psychologowie) że ma ona charakter „krzykliwy” ${ }^{17}$. Nie u Miłosza. W wierszu przykuwa uwagę nie tyle jej ekspresja, ile raczej jej skala. Jest w niej

\footnotetext{
13 Miłoszowe pytania o zło doczekały się monograficznego opracowania w postaci cennej książki Łukasza Tischnera Sekrety manichejskich trucizn. Miłosz wobec zła, Kraków 2001.

14 Ten akurat wątek refleksji nad osobą (kontynuując myśl Maxa Schelera) w sposób szczególny rozwijał Jacques Maritain. Por. Stanisław Kowalczyk, Wprowadzenie do filozofii J. Maritaina, Lublin 1992.

15 Panoramę personalistycznych ujęć osoby przedstawia m.in. Wincenty Granat w książce Osoba ludzka. Próba definicji, wyd. II popr. i rozszerz., Lublin 2006. Problem samopoznania osoby został omówiony w podrozdziale Poznawalność podmiotowego ,ja”, s. 178-181.

16 Emmanuel Mounier, Wprowadzenie do egzystencjalizmów oraz wybór innych prac, przekł. Ewa Krasnowolska, Kraków 1964, s. 57.

17 Por. Borys Jacek Soinski, Nawrócenie religijne, w: Podstawowe zagadnienia psychologii religii, praca zbiorowa pod red. Stanisława Głaza, Kraków 2006, s. 405.
} 
coś z dotknięcia ostatecznego horyzontu bytowania, coś z dotknięcia apokatastasis. Bohater Późnej dojrzałości staje się świadkiem kosmicznego „odczynienia” - przywrócenia świata początku, rzeczywistości przed-historycznej, której nie dotknął jeszcze dramat niezgody i przemijania ${ }^{18}$. „Wielki Powrót” odsłania zrazu swój wymiar moralny - znów zjawia się krajobraz, by można go było opisać lepiej niż dawniej. Znów zjawiają się ludzie, by lepiej niż dawniej można było z nimi współ-czuć.

W twórczości autora Esse etyka nie może jednak obyć się bez ontologii ${ }^{19}$. Zarysowana przez niego możliwość moralnej rehabilitacji dokonuje się w ramach kosmicznego ,powrotu Ojca” i rekapitulacji wizji świata jako rodzinnego domu. Zagadkowe zdanie o „dzieciach króla" rozjaśnia swój sens nie tylko w kontekście topiki biblijnej, ale także dzięki odniesieniom do innych tekstów poety. Motto Elegii dla Ygrek Zet zostało zaczerpnięte z tekstu Martina Bubera. Brzmi: „Nigdy nie zapominaj, że jesteś synem Króla"20. Powraca w kolejnych frazach, odbija się w apostrofach do adresatki: ,jeżeli byłaś córką króla, to nie wiedząc o tym" (w. 9), ze szczególna mocą wybrzmiewa w Post Scriptum elegii:

Nad nami wszystkimi odprawiam gorzkie żale.

Chciałbym, żeby każdy i każda wiedzieli, że są dziećmi króla

I byli pewni swojej duszy nieśmiertelnej,

18 Grecki termin apokatastasis w dosłownym sensie oznacza właśnie „odczynienie”, w teologii funkcjonuje jako określenie przywrócenia rzeczywistości sprzed Grzechu Pierworodnego. Szerzej o idei apokatastasis w poetyckim świecie Miłosza pisze Jerzy Szymik w monografii Problem teologicznego wymiaru dzieła literackiego Czesława Miłosza, Katowice 1996, s. 371-376. Najbliższym kontekstem zdania o rzeczywistości, w której nie zaistniał jeszcze podział na Tak i Nie jest fragment pojawiającego się w tym samym tomie Traktatu Teologicznego. W jego dziewiątej cząstce natrafiamy na słowa: ,[...] dlaczego taki a nie inny / jest porządek stworzenia - na to starali się odpowiedzieć / hermetycy, kabaliści, alchemicy, rycerze Różanego / Krzyża [...] A oni właśnie zajmowali się tym, co zaszło w łonie / Bóstwa przed tym błyskiem, czyli jak pojawiło się Tak / i Nie, dobro i zło" (Druga przestrzeń, s. 71, w. 6-8, 14-15). Nie wdając się w szczegóły Miłoszowej interpretacji fenomenu zła i upadku (omawia ją J. Szymik, dz. cyt., s. 268-278) powiedzmy, że rzeczywistość sprzed „Tak i Nie” jest pierwotną harmonią wszystkiego we wszystkim, rzeczywistością, w której fenomen zła jeszcze się nie pojawił.

19 Obszerną egzemplifikacją podobnej tezy jest m.in. cytowana książka Łukasza Tischnera Sekrety manichejskich trucizn...

20 Czesław Miłosz, Nieobjęta ziemia, Kraków 1988, s. 96-97. 
To znaczy wierzyli, że co najbardziej ich własne jest nie do zniszczenia I trwa jak rzeczy, których dotykaja,

Teraz widziane przeze mnie za granicami czasu:

Jak grzebień, słoik z kremem i farbka do ust

$\mathrm{Na}$ pozaziemskim stoliku.

(w. 32-39)

Wydaje się, że to, co można nazwać „epifanią twarzy Drugiego”, co jest odkryciem zobowiązania wobec innych, początkiem empatii, czerpie u Miłosza swą energię z rozpoznania osobowej wartości samego siebie oraz Innego, z ujawnienia jego i własnej godności „dziecka Króla" - takiej zatem własności osoby, która ma swe źródło nie tyle w aksjologii, co w ontologii. Początkiem autentycznych więzi międzyludzkich (Buber powiedziałby - początkiem spotkania) staje się w świecie poetyckim Miłosza zarówno „stawanie się osobą”, jak i poczucie trwałego zakorzenienia osób w Bycie Absolutnym, świadomość ,że to, co najbardziej własne, jest nie do zniszczenia”. Przełom duchowy, jakiego doświadcza bohater Późnej dojrzałości, pozwala mu na odkrycie ontycznego fundamentu przeczuć niepowtarzalności i niezniszczalności osób. Podstawę do podobnych oczekiwań daje mu rozpoznane zapośredniczenie ludzkiej tożsamości w tożsamości Absolutu, doświadczenie ,ja” jako dziedzictwa i podobieństwa do „Ja” królewskiego, które nie zna czasu, nie doświadcza pęknięcia między możliwością i aktualnością. Autentyczność i intensywność opisywanego w wierszu przeżycia głębokiej jedności ze światem, niezwykłego uspokojenia i pogodnej afirmacji tego, co jest, ma swe źródło w tej samej nadziei, która jest przekonana o głębokiej więzi bytów niekoniecznych z Bytem, który istnieje koniecznie. Horyzont nadziei na ocalenie tego, co jest, został wytyczony w świecie Miłosza przez doświadczenie religijne.

\section{Co się naprawdę zmienilo?}

Czy oznacza to, że stajemy w Późnej dojrzałości przed wizją ostatecznej Pełni Świata, opisem Paruzji? - Wydaje się, że nie. Koniec historii jeszcze nie następuje, nie zmienia się paradygmat ludzkiego 
losu. Jak pisze autor, wciąż jeszcze będą powracały „śmiertelne strzały", dawne i całkiem świeże scenariusze przemocy wciąż jeszcze będą domagały się spełnienia - jak wiele zresztą zdarzeń wpisujących się w uniwersalny paradygmat ludzkiego losu. Gorzki to obraz, cisnący na usta niespokojne pytanie: co się zmieniło? Odpowiedź poety jest dość jasna, właściwie była o niej mowa wcześniej: przełom duchowy nie rozwiązuje problemów świata, ale wprowadza nową perspektywę ich pojmowania. Nie niwecząc ostrości niedostatków egzystencji, pozwala - dzięki głębokiemu doświadczeniu nadziei - antycypować przyszłą harmonię i klarowność rzeczywistości. Wewnętrzne drzwi pozwalają bohaterowi wejrzeć w coś, co dopełni się wraz z końcem czasów, już teraz jednak istnieje w postaci zapowiedzi skrytej w strukturze świata.

Mamy zatem do czynienia z zasadniczą zmianą roli bohatera utworu. O ile w pierwszych wersach pojawiał się pod postacią gościa u drzwi, o tyle w dalszej części utworu jawi się raczej jako uczestnik odnowy. Nie jest już tym, który pyta, lecz tym, który świadczy. Powtarzające się „bo" nadaje jego wypowiedzi formę wyjaśnienia. Oto co się zmieniło: przybysz stał się świadkiem nadziei. Zdając sobie sprawę z możliwości zapomnienia o jej źródłach, z tym większym więc zapałem opowiada o swoim przeżyciu: ,jedność wszystkiego w Bogu jest możliwa; właśnie jej doświadczyłem”.

Kluczowa dla zrozumienia wiersza wydaje się zatem nie tyle kategoria poznania, ile raczej doświadczenia. Wiedza bohatera nie jest gnoza, nie jest przeznaczona dla wtajemniczonych, nie rości sobie pretensji do wyznaczania granic wspólnoty zbawionych. Wręcz przeciwnie: układa się w system najprostszych sylogizmów. Choć stanowi odpowiedź na najbardziej niepokojące pytania - o źródła naszych nieszczęść, o nasze miejsce w świecie i nasze ludzkie powinności nie wymaga ani od bohatera, ani od tych, do których się zwraca, wyrafinowanych operacji myślowych, lecz podstawowego, powszechnie dostępnego otwarcia - dziecięcego zaufania i pokory wobec rzeczywistości. Nie ma też w sobie nic z zawłaszczających skłonności cogito. Choć bohater daleki jest od tego, by mówić o zniesieniu bariery pomiędzy ,ja” i „nie-ja” - granicy pomiędzy osobą i światem - to 
jednak wyraźnie podkreśla związek swych rozpoznań z postawą medytacyjnego otwarcia na wszechistnienie, z poczuciem solidarności z cierpiącymi, z empatią wobec nieszczęśliwych. Jego świadectwo nie ma w sobie nic z dyskursu władzy, nie dyktuje go potrzeba panowania, lecz dyspozycyjność.

Gramatycznymi znakami pokonania ograniczeń ego i uchylenia „ja" w stronę innych są w tekście przemiany osobowych form czasowników. Jeszcze w ósmym wersie mamy do czynienia ze strukturą monologowa, z wyraźnie zaznaczonym ego mówiącego, ale od wersu dziewiątego ,ja” wtapia się w zbiorowość, mówi wyłącznie w jej imieniu. Można rzec, że w jakimś sensie rezygnuje ze swej uprzywilejowanej pozycji, przezwycięża pokuse „bycia ponad innymi”, by świadomie usytuować się wewnątrz wspólnoty jako ,jeden z wielu”. Powracające $\mathrm{w}$ ostatnim wersie formy pierwszoosobowe nie tylko nie weryfikują podobnych skojarzeń, ale je wyraźnie utwierdzają. Zakorzeniony w Biblii topos ,dzieci króla” zmienia się teraz w ewangeliczny obraz robotników w winnicy. I jeden, i drugi odsłaniają dialogiczny charakter naszego życia, jego uwikłanie w relacje z tym, kto jawi się jako jego dawca. Obydwa też są w wierszu poety obrazem wspólnoty - nie tylko tej pomiędzy Stwórcą i stworzeniem, ale także tej która jest możliwa między ludźmi. Każdy z nich akcentuje jakiś jej szczególny aspekt. Pierwszy stanowi swoistą epifanię Ojca, każe myśleć o egzystencjalnym bezpieczeństwie, o zadomowieniu, o doświadczeniu ufności i opieki. Drugi wydaje się bardziej związany z ludzką „,dorosłością” - z rozpoznaniem powinności, z poczuciem misji i odpowiedzialności. Bohater wiersza na nowo odkrywa ,zananą mu od zawsze" prawdę o swoim miejscu w świecie i swoim zadaniu. Co więcej: dostrzega społeczne znamię powołania. Wewnętrzne drzwi, choć brzmi to paradoksalnie, nie oddzielają go od innych, nie zamykają na świat. Poeta przekonuje, że dzieje się coś zupełnie przeciwnego. Drzwi serca prowadzą ku społeczności „dzieci króla” i „robotników w winnicy" - ku wspólnocie ufundowanej na intersubiektywnym doświadczeniu godności i poniżenia, rozpaczy przemijania i eschatologicznej nadziei na ocalenie wszystkiego, co istnieje. Wśród swych powinności bohater odnajduje imperatyw rozumienia zarówno sie- 
bie, jak i innych. Jeszcze raz wypada przypomnieć Mounierowską wizję osoby: „Istotnym powołaniem człowieka nie jest ani opanowanie natury, ani rozkoszowanie się pełnią własnego życia, ale stopniowa realizacja [...] powszechnego, wzajemnego zrozumienia ${ }^{21}$ ".

W rozmaity sposób Późna dojrzałość ujawnia swe związki z innymi tekstami poety - dzięki mini-autocytatom, parafrazom, aluzjom. Wydaje się, że ma charakter syntetyczny: zbiera w zwięzłą, liryczną całość zasadnicze elementy projektu egzystencji, budowanego w całej rozległej twórczości autora Drugiej przestrzeni. Współczesne dyscypliny wiedzy mówią o dojrzałości społecznej, emocjonalnej, religijnej; mówi się o dojrzałej i niedojrzałej osobowości. Metaforyczne obrazy, z których utkany jest liryk, nie pozwalają na zbytnie uszczegółowienie tytułowego pojęcia. Wydaje się raczej, że jego uogólniony charakter sytuuje przesłanie utworu w kontekście filozofii. Myślę zwłaszcza o personalizmie, który w sposób wyjątkowo konsekwentny posługiwał się kategorią osobowej dojrzałości. Wizja człowieka świadomego swej duchowości, swej godności i niepowtarzalności, dysponującego spójnym obrazem rzeczywistości, który staje się dla niej źródłem nadziei, koncepcja osoby przekraczającej siebie, by wejść w relacje z innymi ludźmi, światem i Bogiem, odkrywającej własne miejsce w świecie i sobie zadane powinności - wszystko to wydaje się bliskie nurtom personalistycznej refleksji o fenomenie osoby. Ocala je Miłosz nie tylko dla poezji, ale także dla nas - dla naszej kultury.

\begin{abstract}
Czeslaw Milosz's poem Późna dojrzatość describes the experience of spiritual breakthrough. His past time hero feels incomplete. Full-time starts for him at the time of "awakening". However, deep experience of "me" leads eventually beyond ego - towards the relations with others. The protagonist recognizes both a personal value of himself and of the others. It is the dignity of a "child of the King", it has its source not so much in axiology, as in the ontology. The described spi-
\end{abstract}

21 Emmanuel Mounier, Co to jest personalizm? oraz wybór innych prac, przekł. zbiorowy, Kraków 1960, s. 222. 
DRZWI DO POKOJU

ritual breakthrough does not solve world's problems, but introduces a new perspective of their understanding. It allows - thanks to a deep experience of hope - to anticipate the future harmony. Internal doors allow the hero to look into something which will become complete at the end of time, yet it now exists in the form of announcement hidden in the structure of reality. 